\title{
NOSSAS LÍNGUAS SÃO CRIOULAS OU “A” LÍNGUA NÂO HÁ: MITO? VERDADE? OU INTERPRETAÇÃO?
}

\section{OUR LANGUAGES ARE CREOLES OR THERE IS NOT “THE” LANGUAGE: MYTH? TRUTH? OR INTERPRETATION?}

\author{
Luiza Katia Castello Branco \\ Universidade do Vale do Sapucaí, Univás, Pouso Alegre, MG, Brasil
}

Resumo: Compreendemos mito e verdade como interpretação, isto é, discurso, aqui definido como efeito de sentido entre interlocutores (PÊCHEUX, 1997). A partir do tema proposto neste número, refletimos discursivamente sobre o conceito de língua crioula pelas relaçōes entre línguas no espaço simbólico de Cabo Verde, país membro da Comunidade de Países de Língua Portuguesa (CPLP). Questionamos o modo como a sociolinguística, ao conceituar língua crioula atualiza a memória do mito da língua de origem, pura, e significa como variação linguística as diferentes materialidades das línguas cabo-verdiana e portuguesa, silenciando, neste espaço, o político constitutivo da tensa e incontornável relaçáo unidade/diversidade.

Palavras-chave: Análise de Discurso; língua crioula; sociolinguística; espaço; sentido.

Abstract: We understand myth and truth as interpretation, that is, discourse, defined here as an effect of meaning between interlocutors (PÊCHEUX, 1997). Based on the theme proposed in this issue, we reflect discursively on the concept of creole by the relations between languages in the symbolic space of Cape Verde, a member country of the Community of Portuguese Speaking Countries (CPLP). We question the way in which sociolinguistics, in conceptualizing the creole language, updates the memory of the myth of the origin language, pure, and means as linguistic variation the different materialities of the Cape Verdean and Portuguese languages, silencing, in this space, the political constitutive of the tense and inescapable relationship unity/diversity.

Keywords: Discourse Analysis; creole language; sociolinguistics; space; meaning. 
Somos nós que pensamos os mitos ou são os mitos que nos pensam?

(C. GINZBURG, Mitos, emblemas e

sinais)

Os senhores descobririam então que nem tudo aquilo que foi relatado sobre Alexandre merece crédito ou pode ser confirmado em seus detalhes; não obstante, não posso supor que os senhores viessem a deixar a sala de conferência com dúvidas sobre a realidade de Alexandre Magno. A decisão dos senhores seria determina$\mathrm{da}$, essencialmente, por duas consideraçōes: primeiro, que o conferencista não tem qualquer motivo imaginável para garantir-lhes a realidade de algo que ele próprio náo julga ser real, e, em segundo lugar, que todos os livros de história disponíveis descrevem os acontecimentos em termos aproximadamente semelhantes. Se continuassem a examinar as fontes antigas, teriam em conta os mesmos fatores - os possíveis motivos dos informantes e a conformidade das testemunhas entre si. $\mathrm{O}$ resultado da pesquisa sem dúvida lhes traria uma confirmação, no caso de Alexandre; no entanto, provavelmente seria diferente quando se tratasse de personagens como Moisés ou Nemrod.

(FREUD, Parte I-Parapraxias) 


\section{A questáo/As questóes}

Neste texto, procuramos discutir discursivamente a afirmação que trazemos como título: nossas línguas são crioulas, e sua paráfrase: "a” língua não há: verdade? Mito? Ou interpretação? Esclarecemos que o "nossas" remete aos países de língua oficial portuguesa colonizados por portugueses e atuais membros fundadores da Comunidade dos Países de Língua Portuguesa - a CPLP'; o "crioulas" aponta para a falta de pureza, para a mistura constitutiva de nossas línguas. E a paráfrase dá visibilidade à contradição de que não há uma língua portuguesa apenas, mas várias e impuras, e que as línguas significadas como variantes da língua portuguesa, não o são. Buscar descobrir de que mistura se trata leva a determinar uma delas como origem, já que o discurso científico linguístico se ocupa em classificar, hierarquizar, institucionalizar e disciplinar sentidos para as línguas.

Isso posto, trazemos para a discussão três questóes básicas que se imbricam. Uma primeira, sobre o sentido de verdade e mito, que exploramos pela dimensão da Análise de Discurso e pela da Psicanálise para compreendermos os efeitos de sentido de verdade científica e de sujeito da ciência linguística. Uma segunda que diz respeito às fronteiras epistemológicas entre a Sociolinguística e a Análise de Discurso para nos situarmos teoricamente em relaçáo ao conceito de "língua crioula". E uma terceira que coloca em movimento as outras duas, questionando o discurso científico linguístico sobre o modo como conceitua "língua crioula", e, ao fazê-lo, interdita às línguas cabo-verdianas - nosso objeto de estudo - um lugar sempre já reservado às línguas europeias (“aparelho de línguas") (BALIBAR, 1985).

\footnotetext{
${ }^{1}$ A CPLP foi fundada a partir de um imaginário de homogeneidade linguística, que produz a evidência de que há "uma" e a mesma língua portuguesa falada nos seus oito países membros e de que todos os seus cidadáos falam essa mesma língua. Compreendemos que o gesto de formaçáo de uma comunidade como a CPLP, tal como está concebida, faz silenciar sentidos como o da heterogeneidade própria à língua portuguesa, o da sua relação assimétrica com as outras línguas faladas nesses países, e o das diferentes historicidades determinantes da e determinadas pela relação sempre política entre sujeitos, línguas e espaços na disputa por significar (BRANCO, 2013).
} 


\section{O espaço cabo-verdiano constituído por seus sujeitos e línguas}

A partir da perspectiva discursiva da História das Ideias Linguísticas em sua especificidade brasileira - um campo de saber que alia "a história da construçáo do saber metalinguístico com a história da constituição da língua nacional, visando trazer contribuição ao modo de pensar e trabalhar a questão da língua nos países de colonização" (ORLANDI, 2001, p. 7) -, propomos a discussão sobre as línguas em espaço ${ }^{2}$ cabo-verdiano dando visibilidade ao funcionamento da palavra "crioulo" nos discursos sobre a(s) língua(s) de Cabo Verde, mais especificamente ao discurso científico da sociolinguística.

Interessou-nos, nessa pesquisa ${ }^{3}$, o discurso sobre a língua por ser o lugar em que se dá o encontro entre a(s) memória(s) da(s) língua(s) e a história que a(s) constituiu. Para compreender a historicidade da(s) língua(s) em espaço cabo-verdiano, tomamos o discurso sociolinguístico sobre os termos "crioulo/língua crioula", considerando que a questáo da produçáo de sentido é um processo histórico-discursivo imbricado ao processo de constituição do sujeito (ORLANDI, 2001), sob condiçôes de produção materiais específicas. Em nossas análises, chegamos a uma rede de discursividades que deram visibilidade à contradição no modo como as línguas funcionam em espaço cabo-verdiano. Pelas relaçóes de sentidos que as definiçôes dos termos

\footnotetext{
${ }^{2}$ Essa expressão "em espaço" surgiu-nos por não saber denominar essa língua portuguesa que já nấo é a mesma língua portuguesa que vem com o processo de colonizaçáo. Essa ideia veio a partir da expressão "em solo", cunhada pela Profa. Dra . Vanise Gomes de Medeiros, em um artigo seu, "A língua em solo brasileiro na Revista Brasileira no período JK" (2008), para discutir sobre a especificidade da língua em solo brasileiro na Revista Brasileira no período JK” (2008), para discutir sobre a especificidade da língua portuguesa em solo brasileiro que comparece nos artigos do periódico Revista Brasileira nos anos JK. Assim, a expressão "em espaço" diz de uma língua portuguesa oficial, que, a nosso ver, acaba se significando e sendo significada como outras línguas também chamadas de portuguesas, pois se singularizam em espaço: brasileiro, moçambicano, cabo-verdiano, guineense, santomense, angolano, e, inclusive, português. Essas línguas não são a língua portuguesa imaginária nem a língua portuguesa fluida de Portugal (ORLANDI, 2009, 1988); são outras línguas portuguesas (cada uma delas com um funcionamento imaginário e outro fluido), com suas especificidades, memórias e historicidades que, discursivamente, não garantem nem a desejada unidade nacional instituída pelo Estado, nem a unidade linguística "timbrada" e tâo decantada pela CPLP, motivo precípuo para organização de uma comunidade como esta. Nesse gesto de precisar dizer dessas línguas portuguesas como outras, pensamos sujeito/espaço como formas históricas de existência, que constituem sentidos e são por eles constituídos.

${ }^{3}$ Pesquisa realizada durante o mestrado defendido em 2007, IL/UFF, Niterói/ RJ, e que motivou o doutorado defendido em 2013, IEL/Unicamp.
} 
"crioulo/língua crioula" estabelecem com as noçôes de "língua materna", "língua oficial" e "língua nacional", observamos que não há recobrimento, tendo em vista que, em Cabo Verde, a língua crioula também chamada de lingua materna náo é a oficial, mas é uma língua diferente da portuguesa, e é considerada como língua nacional. Esse náo recobrimento, em nossa pesquisa, pôde ser compreendido como uma falha, aquilo que não comparece no dizer da sociolinguística sobre a língua cabo-verdiana, ou porque escapa, ou porque se apaga. Esses dizeres que náo se inscrevem permanecem, e seguem produzindo efeitos de sentido atualizados por uma memória hegemônica desde sempre narrativizada a partir das políticas colonizadoras linguísticas europeias; uma memória do dizer que organiza os sentidos de modo a tornar homogêneas as línguas (a língua cabo-verdiana como se fosse variante da língua portuguesa de Portugal e a língua portuguesa como se fosse única e mesma) e seus falantes (como se fossem povos irmãos e nunca tivessem sido colonizados/escravizados). Assim, apesar de filiadas a discursividades distintas e a memórias heterogêneas, essas línguas e esses sujeitos são determinados discursivamente pela memória da colonização. De um lado, pela linha da variação linguística, o discurso científico busca, na materialidade das línguas cabo-verdiana e portuguesa, pontos de semelhança entre elas, para filiar a primeira como "derivada" ou "variante" da segunda - apesar de as diferenças fonológicas, morfológicas, sintáticas e lexicais serem muitas e inscreverem-se na forma material das línguas deixando marcas que problematizam a ideia de variação; e, de outro lado, pela linha de uma "história comum", esse mesmo discurso busca filiar o imaginário cabo-verdiano de nação como sendo Cabo Verde ainda "extensão" de Portugal: povo "irmão" que fala a "mesma" língua, "o" português levado por/"herdado" de Portugal. Dessa forma, apagam-se da relação entre naçôes o conflito, os sentidos do diferente, as contradiçóes; e, pela via da "fraternidade", faz perderem-se, nessa relaçáo, o caráter político, a historicidade dos sujeitos/línguas/espaços em suas singularidades.

As línguas em Cabo Verde, nesses mais de 500 anos desde o achamento do arquipélago, trazem em sua historicidade uma diversidade de línguas africanas que, no convívio com a(s) língua(s) portuguesa(s) ${ }^{4}$, juntaram-se e

\footnotetext{
${ }^{4}$ Tendo em vista a distinção entre língua fluida e língua imaginária proposta por Orlandi (2009), falamos no plural, pois “o” português que entra nas colônias portuguesas não é a língua imaginária oficial do Estado português, aquela representada como homogênea no imaginário dos sujeitos das colônias. É a língua fluida já em espaços-tempos diferenciados, posta em contato com inúmeras outras línguas africanas na costa ocidental e oriental da África e línguas indígenas no Brasil. É a língua fluida trazida por falantes pertencentes: à nobreza do Reino de Portugal, donatários das capitanias, seus servos, os degredados, os traficantes de escravos, os
} 
produziram línguas outras em toda a força de suas singularidades/multiplicidades, há muito existentes nas ilhas e significadas como língua materna e como língua nacional vivendo as variações e mudanças que constituem todas as línguas. Apesar de haver na constituiçáo uma única língua oficial, "a" língua portuguesa, a relação dos sujeitos cabo-verdianos com as línguas em espaço cabo-verdiano não é de unidade, antes de diversidade. Significar politicamente um espaço pela unificação da língua, não o torna homogêneo linguisticamente, pois não tomamos "unificado" como sinônimo de "homogêneo", já que é possível pensar uma unificação linguística sem, entretanto, apagar a diversidade. Mas, no caso das políticas públicas de língua em Cabo Verde, acaba se produzindo essa sinonímia.

\section{Verdade? Mito? Ou interpretaçáo?}

Rancière (2004, p. 58), quando reflete, náo sobre verdade nem sobre mito especificamente, mas sobre arte e política considerando a relação entre linguagem e história, nos diz, "escrever a história e escrever histórias pertencem a um mesmo regime de verdade"; e, em seguida, nos diz ainda que "o real precisa ser ficcionado para ser pensado" (RANCIÈRE, 2004, p. 58).

Perguntarmos sobre a questáo da verdade ${ }^{5}$ em suas especificidades e sobre o mito em relaçáo à verdade, pode nos fazer avançar em nossa questão de que não há "a” língua.

Pêcheux, quando constitui seu quadro epistemológico para pensar sua teoria da subjetividade, faz diálogo com o domínio da psicanálise. É bom que se marque aqui a insistência de Pêcheux em colocar questôes fundamentais à teoria trabalhada desde fins da década de 60 . Náo é óbvio para ele repensar a teoria a partir de seu interior (momento teórico-histórico), e nem é confortável habitar uma zona de entremeio fazendo fronteiras às disciplinas com que dialoga, tentando fazer funcionar, no (des)encontro, um possível que exige um constante "deslocamento de fronteiras entre as disciplinas, afe-

escravos que falavam português, e os línguas (ou chalonas, intérpretes multilíngues, africanos livres ou não, que deveriam aprender a falar "o" português, os "crioulos" e as outras línguas africanas e indígenas devido à diversidade dos povos escravizados, pois eram os intermediários na comunicação entre estes e os europeus).

${ }^{5}$ Algumas indagaçóes poderiam ser: quem tem a verdade? Onde ela está? Cada um tem a sua? Há uma verdade universal? Há uma mais verdadeira que outra? Ou mais mentirosa? Há a meiaverdade? E o mito é uma verdade? Seriam intepretaçôes? Seriam funcionamentos imaginários? E a verdade científica é mais verdadeira? O mito pode ser científico? 
tando profundamente seu regime de verdade, uma vez que essas disciplinas são provocadas por suas margens" (PÊCHEUX, 2016 [1981], p. 28-29). E essa inquietude não é diferente com a Psicanálise.

Estando advertidos disso, fazemos uma tentativa de responder à pergunta formulada no título, apresentando a seguir o modo como tanto a Análise de Discurso quanto a Psicanálise formulam sobre verdade - como efeito.

Freud (2006 [1939]), em Moisés e o Monoteísmo, ao considerar um conceito como verdade, nos diz que aí está em jogo a suspensão do juízo. A suspensão do juízo se calça na falta de certeza a partir de uma aposta; não julga nem verdadeiro nem falso um dizer, ou, então, considera a possibilidade de ele ser tanto verdadeiro quanto falso, ao mesmo tempo. Nesse sentido, Freud abre espaço para a contradição e, no seu percurso de escrita do próprio texto, lida o tempo todo com isso. Diz que uma contradição não é uma refutação. Assim, o discurso da psicanálise comporta a contradição diferentemente do da ciência cartesiana. Freud encara os pontos indiscerníveis, não comprováveis, como pontos de reflexão que lhe permitem elaborar uma série de hipóteses, pois não há relação entre o fato e a construção sobre ele. A argumentação lógica não leva à verdade em Freud. É o caminho que prova que há a verdade, e esta é desdobrada na argumentaçáo, pois o modo de dizer, a formulaçáo, é a mensagem.

Lacan, em seu percurso teórico, formula sobre a noção de verdade de diferentes modos, conforme Porge observa em seu texto "A ronda dos semi-ditos claros". Em seus modos de dizer, encontramos: "A verdade tem uma estrutura de ficção" (1953); "Eu, a verdade, falo" (1955); "Não se pode dizer a verdade sobre o verdadeiro" (1960); "Há uma divisão entre o saber e a verdade" (a partir de 1961); "A verdade se suporta num semi-dizer" (1970). Lacan explora na sua escrita a variabilidade de concepção posta no significante verdade e aposta no termo varidade, isto é, a verdade variável. Traz, a partir de sua ronda pela varidade, a questão da transmissão da experiência clínica da psicanálise que passa pela verdade dessa experiência, como forma de assegurar a credibilidade do saber e do método. Assim, podemos compreender, que a noção de verdade é significada como a meia-verdade, a verdade não-toda, porque, de certa forma, na psicanálise, trabalha-se com uma escuta da fala do outro, dos significantes que aí comparecem, tentando tamponar uma falta, mas podendo desvelar o que é da ordem de um não-saber.

Para Freud (1980 [1937]), não há análise sem amor à verdade. Para Lacan (1992 [1969/70]), aí deve ser situado o amor à castração, de modo 
que a verdade está ligada à impotência e ao que é da ordem do impossível. Então, é de um efeito de verdade que se trata, e esse efeito é justamente uma queda de saber, uma vez que é próprio da verdade sempre se ocultar (COELHO, 2007).

$\mathrm{Na}$ Análise de Discurso, a questão da verdade é uma questão de interpretação, de efeito de sentido; procura não pelo sentido "verdadeiro", mas pelo real do sentido em sua materialidade linguística e histórica (ORLANDI, 2003). Pêcheux (1997 [1975]), ao pensar a possibilidade de uma teoria do discurso materialista na contramão do formalismo (que busca o que é único, universal, constante nas línguas em geral) e do sociologismo (que busca o que é múltiplo, diverso, variado nas línguas em particular), inscreve esse momento epistemológico como uma crítica à afirmação do óbvio, expondo a contradição; advertência àquilo que, em seu funcionamento histórico-ideológico, se torna evidente, e, portanto, verdade. Ao intitular seu livro como "Les vérités de la Palice" - "uma crítica bem-humorada à semântica formal" - notamos que a palavra verdade comparece e no plural. Esses dois fatos nos lembram de que a questáo do sentido é central - a interpretação: limites entre o mesmo (não há sentido sem repetição) e o diferente (movimentos distintos de sentidos); manifestação do inconsciente e da ideologia na produção dos sentidos e na constituição dos sujeitos (ORLANDI, 2003). Esses dois fatos nos lembram também da questão posta por ele em sua empreitada teórica com relaçáo à semântica, "o que estaria determinando essa estranha circularidade [seu retorno] que se efetua sob as aparências de um desenvolvimento?” (PÊCHEUX, 1997 [1975], p. 63).

Voltando à nossa questão inicial, “" língua não há, perguntamos como é essa questão da verdade para o sujeito da ciência ou do conhecimento. Compreendemos que a complexa relaçáo entre sujeito, conhecimento, ciência, história e língua quando tratada na evidência, na transparência dos sentidos, faz crer que conhecimento e informação são sinônimos, que história se faz a partir de arquivos repletos de conhecimento/informação "verídica", e que esse sujeito não pode dizer senão a verdade toda e global: uma verdade precisa, quantificável e mensurável, atestada pela prática científica através de seus instrumentos certos, próprios e acurados. Como nos diz Foucault (2006, p. 302), em sua pequena história da verdade, essa verdade positivista está ligada "a certa tecnologia da construção ou da constatação em direito universal da verdade, uma tecnologia da demonstraçáo". Assim, nessa evidência de verdade, fica silenciado que o resultado é interpretação, é efeito de sentidos produzidos sob determinadas condições de produção, portanto não sendo único nem neutro, ou seja, este resultado vem filiado a 
redes de memórias.

Dessa forma, a "origem”, a "verdade", o "único", o "todos", o "tudo", o "completo", o "abrangente", o "conhecimento", a "informação" são significantes que se reproduzem num sujeito que é posição (cientista), não uma coisa em si mesma, uma substância (HENRY, 1997 [1983]). E mais, esse sujeito é constituído por esquecimentos: o de pensar que é fonte do dizer e que pode dizer tudo; e o de desconhecer o seu assujeitamento ideológico e histórico (PÊCHEUX, 1997 [1975]). E, inexoravelmente, esses esquecimentos fundantes do sujeito enquanto posição se reproduzem nos dizeres dessa ciência que se quer formalista, positivista, empirista, sociologista. Parece não haver outra forma de estar nessa ciência, em especial a do século XXI, se não pela via da certeza, da quantidade, da aferição, do mensurável, da evidência da verdade e da objetividade científica. Esses são efeitos ideológicos de uma determinada situação histórica, e devem ser considerados ao se pensar a noção de "sujeito da ciência" ou "sujeito do conhecimento", no caso o sujeito cartesiano, como sendo "um efeito ideológico particular (suscetível de tomar diversas formas históricas), resultando de um desdobramento da forma-sujeito" (HENRY, 1992 [1977], p. 143-144).

Compreender essa posição sujeito da ciência passa por compreendermos a noção de forma histórica capitalista do sujeito individuado nessa relação com o Estado sustentado pelo jurídico, pela discursividade das instituiçôes, cujas posiçôes são projetadas no discurso, a partir de um lugar social e de um imaginário (ORLANDI, 2001a). Compreendemos que essa passagem que faz o sujeito individuado, que sofre o processo de individuação de determinada maneira, vai levá-lo a formas de identificação em relação a uma formação discursiva a partir do que se constituem as tais posiçôes sujeitos que vão fazê-lo significar desse ou daquele jeito - aí se tem a posição sujeito na sociedade.

Concluímos, então, por ora, que a verdade (e seus outros nomes, por exemplo, mito) significa como efeito de sentido, pré-construído, interpretação que ao mesmo tempo que faz existir/institucionalizar a história como oficial, como verdade científica, não o faz sem estar apontando, mesmo sem querer, para a existência de outras histórias, de outras verdades, de outros efeitos de sentido, porque ao narrar, já não narra o fato, mas sua versão sustentada pela memória discursiva - o real é sempre ficcionado porque simbolizado (RANCIÈRE, 2004). 


\section{Fronteiras epistemológicas: os (des)encontros entre Análise de Discurso e Sociolinguística}

É possível fazer conversar a Sociolinguística com a Análise de Discurso se pensarmos não só as fronteiras que as separam, mas os sentidos que (não) compartilham, um diálogo talvez insatisfatório em que, ao invés de unir os lugares, coloca-os em suspensão.

Pensando no comum, as duas teorias se tangenciariam no que respeita à relevância da relação entre o social e o linguístico; à consideração da língua como processo social, como não-autônoma, como língua de um sujeito, concreta e heterogênea; à crítica que ambas fazem ao caráter homogêneo da língua; à sistematizaçáo das regularidades da variação linguística; e ao domínio de interesses já que a Sociolinguística analisa a linguagem no contexto da sociedade (ORLANDI, 1983, p. 103).

As duas epistemes se distanciam bastante, quando compreendemos que, para a Análise de Discurso, na língua, o social e o histórico coincidem; quando considera língua como trabalho humano transformador, como produto histórico-social; quando entende a heterogeneidade como constitutiva da língua, como funcionamento do discurso do seu interior com o seu exterior; quando propóe a relaçáo da linguagem com a exterioridade como uma relação de simultaneidade, de constituição, e, não, de causalidade, como na Sociolinguística.

A maior diferença de epistemes, todavia, repousa sobre a natureza do objeto teórico de estudo determinante do arcabouço teórico-metodológico que engendra especificidades particulares a uma e a outra. Enquanto a Sociolinguística tem como objeto a língua, a Análise de Discurso tem o discurso e, por isso, articula conceitos como os de processo de produçáo e condiçóes de produção sócio-históricas em que o discurso é produzido.

A Análise de Discurso é uma teoria que trabalha com a noção de funcionamento da materialidade linguageira e com a articulação de processos constitutivos de relaçôes do/no discurso. Consequentemente, o sujeito desse discurso, não é o mesmo sujeito da língua da Sociolinguística. O sujeito da Análise de Discurso não se apropria da linguagem por ele mesmo, existe uma forma-sujeito social de apropriar-se dessa linguagem (de habitar a língua) que constitui o jogo do lugar social e dos sentidos estabelecidos e da ilusão desse sujeito interpelado pela ideologia e determinado sócio-historicamente. 
O contexto de que os trabalhos de análise sociolinguística tratam como o exterior linguístico em que a língua o reflete não é aquele que a Análise de Discurso considera como exterior. A Análise de Discurso procura tratar dessa exterioridade da língua numa relação constitutiva do discurso e do sujeito com o processo sócio-histórico e a ideologia.

A perspectiva de uma linguística que faz reflexóes acerca do funcionamento dos processos linguageiros de forma hegemônica, que se quer ciência-mor dos estudos das línguas naturais, que se pretende lúcida, clara, unívoca e homogênea em seu discurso sobre as línguas humanas, é aquela que, dentre outros sentidos, estabelece como verdade científica que as línguas crioulas são diferentes das outras, pois possuem uma variabilidade específica e maior que a das outras línguas ditas naturais, possuem uma universalidade estrutural e permitem reconstituir o processo que lhes deu origem, por isso merecendo um campo de estudo à parte como o da crioulística.

Compreendemos que da reflexão linguística sobre a linguagem precisa fazer parte, porém, não só uma atitude crítica e atenta do sujeito-cientista sobre seus próprios passos - já que este está também filiado a formaçôes discursivas e ideológicas determinadas sócio-historicamente -, mas também o re-conhecimento da relaçáo de simultaneidade que faz com que a língua seja comunicação e não-comunicação; re-conhecimento de que é a materialidade da língua que torna possível o jogo ${ }^{6}$ próprio da língua para o sujeito, já que dela são constitutivos o equívoco e a falha, o político e o histórico.

$\mathrm{Na}$ próxima seção, limitar-nos-emos a um gesto analítico que conduza à compreensão dos sentidos já estabelecidos como hegemônicos sobre linguas crioulas buscando dar visibilidade à historicidade que esse dizer científico-linguístico traçou ao se construir.

\section{O discurso científico da Sociolinguística sobre as línguas crioulas}

No século XIX, os filólogos, no século XX, também os linguistas, nos finais dos anos 60, os sociolinguistas e, mais especificamente, os crioulistas - que reivindicam um espaço para a crioulística ao lado da linguística - têm dado uma especial atenção ao estudo dos crioulos, como atestam os numerosos congressos, simpósios, mesas-redondas, publicaçóes de artigos e livros sobre o assunto, numa tentativa de, ao tratá-los cientificamente, dar-lhes o

\footnotetext{
${ }^{6}$ Esse jogo, segundo Pêcheux, "quer dizer o impulso metafórico interno da discursividade, pelo qual a língua se inscreve na história” (2010 [1994], p. 58).
} 
diagnóstico de línguas naturais, pois, até a segunda metade do século retrasado, essas línguas eram tratadas como "cicatrizes, degenerescências linguísticas, sem forma criadora; não sistemas em si, mas amálgamas ou desvios de outros sistemas" (CUNHA, 1981, p. 37).

A partir da leitura do arquivo, Hugo Schuchardt (1842-1927), considerado o pai da crioulística, Adolfo Coelho (1847-1919), considerado também o pioneiro da investigaçáo sistemática dos crioulos, e Leite de Vasconcelos (1858-1941), filólogo sistemático e rigoroso, em seus dizeres sobre as línguas ditas crioulas, como sujeitos da ciência linguística, vão constituir em seus gestos de denominação e classificação sentidos para essas línguas, de acordo com as condiçôes de produção sócio-históricas da época. Esses cientistas da linguagem enunciam do lugar de filólogo (alemão e portugueses, respectivamente), numa época em que a ciência se interessava pelos fatos linguísticos em sua história cronológica, pela classificação genética de suas unidades e relaçóes, pela origem dos elementos e pela pureza das línguas.

Apesar de ainda não se distinguir crioulos de pidgins, Adolfo Coelho, por exemplo, inicia a compilação de dados sobre diversos crioulos existentes no mundo, consequentemente, reúne a primeira bibliografia abrangente sobre essas línguas, e enuncia, em 1881, leis gerais para explicar a sua formação, demonstrando estar à frente de sua época. Diz ele:

$1^{\circ}$ Os dialectos românicos e crioulos, indo-português e todas as formações semelhantes representam o primeiro ou primeiros estádios na aquisição de uma língua estrangeira por um povo que fala ou falou outra (COELHO, 1881, p. 102).

$2^{\circ}$ Os dialectos românico-crioulos, indo-português e todas as formações semelhantes devem a origem a acçâo de leis psicológicas ou fisiológicas por toda a parte as mesmas e não a influência das línguas anteriores dos povos em que se acham esses dialectos (COELHO, 1881, p. 105).

O primeiro princípio associa o surgimento dos crioulos à questão da aprendizagem de segunda língua, que, hoje, para a crioulística, é uma das questóes mais instigantes, já que apresenta íntimas relaçóes com o que se dá nas línguas pidgin e crioulas. $\mathrm{O}$ segundo princípio antecipa em quase cem anos a moderna hipótese do bioprograma linguístico de Derek Bickerton, que propóe que as características dos crioulos fornecem poderosos 'insights' para o estudo do desenvolvimento da linguagem no indivíduo e para a determinação de características linguísticas na espécie humana.

Schuchardt opunha-se ao estudo puramente linguístico da história 
das línguas, e defendia a questáo de que toda língua apresenta algum grau de mistura. Foi ele que "associou a expressão língua mista (mischsprache) a pidgin-crioulo” (DeCAMP, 1971, p. 31, apud COUTO, 1996, p. 151).

É a era do comparativismo oitocentista, do método comparativo-reconstrutivista, que garante um estatuto científico aos trabalhos sobre a evolução das línguas, aproximando a linguística da biologia, e servindo como metáfora ideal para a ordem natural na sucessão das espécies - foi o próprio Charles Darwin que tomou a iniciativa de utilizar o exemplo linguístico, sobre a evolução regular de traços fonológicos das línguas Indo-europeias, como termo de comparação em uma de suas exposiçôes.

A busca por uma família de línguas que relacionasse as línguas dos Estados europeus a línguas da Antiguidade como o Sânscrito, o Grego e o Latim para justificar a visada da pureza, do padrão, da correção linguística de modo a valorizar essas línguas europeias fez surgir o método de classificação genealógico, proposto pelo linguista alemão Shleicher. O objetivo era determinar as relaçóes históricas que as línguas estabeleciam entre si. Os gramáticos comparativistas atribuíam um antepassado comum a línguas de mesma família estabelecidas as relaçôes de proximidade ou afastamento de acordo com as semelhanças e diferenças formais existentes entre elas.

Do ponto de vista das relaçôes genealógicas, grande parte das línguas pode ser classificada em termos de família genética, por ter apenas um progenitor, uma língua-mãe. Tem-se a certeza da procedência da língua. Porém muitas há que esse modelo não explica por não terem uma "transmissão normal", isto é, por terem mais do que um progenitor. Estão, nesse caso, as chamadas linguas mistas as quais não podem, por definição, ser filiadas num ou noutro deles. Isto é, não se podem classificar essas línguas em termos de "produtos" de uma transmissão normal de um dado progenitor. Se, segundo esse método, a transmissão opera sobre a totalidade da gramática de uma língua, no caso das línguas mistas isso nấo ocorre. Elas podem partilhar a sintaxe com o progenitor A, a fonologia com o B, etc. Dessa forma, tanto A quanto $B$ sofrem rupturas na sua transmissão como um todo, quando concorrem apenas parcialmente para a construção de uma nova língua.

Assim, sendo a origem dessas línguas dita não-genética, a sua caracterização exige uma metodologia que, além dos parâmetros linguísticos, integre parâmetros sócio-históricos, pois essas línguas surgem em comunidades que se encontram em situaçóes de mutação social, por vezes de tensão social. A partir daí, os cientistas da linguagem procuram uma origem e uma árvore genealógica para os pidgins e crioulos. 
Pode-se dizer que esse procedimento científico se estende até hoje, século XXI, como veremos mais adiante. As línguas chamadas crioulas constituem "verdadeiros laboratórios" de estudo "pelo fato de aí [nesse estado linguístico] elas aparecerem em sua plenitude, e náo camulladas por acidentes históricos que se deram frequentemente há muitos séculos e que, portanto, são inacessíveis à observação direta" (COUTO, 1996, p. 205).

Nessa classificação científica, levam-se em conta os fatores sociais e históricos concomitantes ao surgimento de uma língua desse tipo. Desse ponto de vista, a existência de contato linguístico supóe o contato social dos respectivos falantes, enquadrados em situaçóes de comunicação de ordem diversa; a estas, subjazem relaçôes sociais, políticas e culturais igualmente diversificadas e que condicionam as relaçóes linguísticas.

Está, dessa forma, justificada a recorrência feita por quase todos os cientistas da linguagem em querer tratar numa categoria à parte essas línguas. Diz-nos Couto (1996, p. 35),

o fato importante a ser retido aqui é que, levando-se em conta apenas a estrutura, não é possível distinguir os crioulos e os pidgins como uma categoria à parte. Só as condiçôes sociais de seu surgimento os separam das línguas não-crioulas ou pidgins. Até o presente momento, "não há nenhuma maneira segura de identificar como crioulo uma língua cuja história seja desconhecida” (DeCAMP, 1971, p. 25).

Ainda, nesse sentido, escutamos Tarallo (1987, p. 15) dizer que esse tipo de língua foi "inúmeras vezes detectado em outras partes do mundo, em outras épocas, mas sempre decorrente das mesmas circunstâncias sociais", a saber, de relaçóes estritamente comerciais ou via escravidáo.

Nesse entrelaçar de razóes para justificar um lugar de exceção para essas línguas - diferente em tudo das línguas não-crioulas: origem, consequente estrutura, processo de aquisição -, chega-se à conclusão de que dizer língua crioula implica dizer língua fora do grupo das línguas naturais, já que sua "origem" é determinística de seu processo de mudança linguística, pois são classificadas como línguas muito instáveis. E, ao mesmo tempo, esse dizer nega o sentido de contato e de mescla às línguas não-crioulas, fazendo-as significar como línguas não-mistas. Dessa forma, entender-se-ia o português como uma língua vinda direta do latim, sem contatos com outras línguas, uma vez que o português é uma língua não-crioula nesse raciocínio ${ }^{7}$.

\footnotetext{
${ }^{7}$ Silencia-se nesse dizer sobre a língua portuguesa que ela dividiu/disputou espaço, no mínimo,
} 
Ao mesmo tempo, o termo crioulo ganha derivaçóes e passa a dar nome a novos conceitos e processos linguísticos. Os processos como pidginização ou jargonização, crioulização, recrioulização, descrioulização, hipercrioulização, rejargonização ou repidginização são característicos para descrever a natureza "instável" do léxico e da gramática dos pidgins e crioulos. Nesse dizer sobre as línguas crioulas, há sentidos que apontam o grau de mutabilidade/ metamorfose/mudança linguística de forma bem diferenciada em relação às línguas não-crioulas. Dizem que a tal ponto essas línguas são mutantes que são mensuráveis numa escala de gradação cíclica que registra extremos, como por exemplo, nudarem tanto até voltarem a ser a língua europeia que lhes deu origem, isto é, nos explica Couto (1996, p. 18), "se a língua de superstrato (sempre europeia) continuar presente (como na Guiné-Bissau, em Cabo Verde, no Havaí, no Haiti, etc.), o crioulo tende a continuar se expandindo, desta vez na direção da língua europeia. Trata-se do processo da descrioulização".

É paradoxal pensar que: 1) se os crioulos são línguas mistas, com origem em mais de uma língua, como o contato e a mescla entre as línguas se desfazem em um ponto determinado e de forma táo transparente e pontual? 2) se o processo de crioulização, apesar de ser conceituado com base na natureza das línguas crioulas, quer dizer "expansão na forma interna da língua, com convergência no contexto de extensão do uso" (HYMES, 1971, p. 84), então todas as línguas podem sofrê-lo, inclusive as não-crioulas.

O ciclo vital (HALL, 1967, p. 151-156) estabelecido pela sociolinguística para descrever o nascimento de um crioulo, ao mesmo tempo, explica a formaçáo e revela a mudança. O processo seria: parte-se sempre de um pidgin instável ou jargão (1), para um pidgin estável (2), para o crioulo (3) e para a língua dominante (4). Assim, há o processo de pidginizaçâo entre as fases (1) e (2), o processo de crioulização entre as fases (2) e (3), e o processo de descrioulização entre as fases (3) e (4). O processo de recrioulização aconteceria entre as fases (4) e (3) em determinadas circunstâncias, como por exemplo, para afirmar a identidade do povo que fala o crioulo, enfatizando a língua crioula de seus antepassados. "O mesmo fenômeno deve estar-se dando entre os cabo-verdianos, os guineenses e os são-tomenses de Lisboa" (ROMAINE, 1988, p. 188-203 apud COUTO, 1996, p. 20).

O processo de hipercrioulização, ou seja, "afirmação agressiva da diferença crioula e do status superior do crioulo" seria o mesmo processo da

com um grande número de línguas que ali existiam significando seus espaços e seus sujeitos, e sendo significada por eles. 
recrioulização (ROMAINE, 1988, p. 188-203 apud COUTO, 1996, p. 20). "A diferença consiste no fato de a hipercrioulização se dar no próprio país em que o crioulo é falado, e não no país de emigração, como ocorre com a recrioulização entre os jamaicanos residentes na Inglaterra" (loc. cit.).

$\mathrm{Na}$ necessidade de buscarem a origem, para explicarem a gênese dos crioulos, os sujeitos do discurso da sociolinguística dizem haver dois caminhos. Aqueles sujeitos sociolinguistas que, na sua maioria, dizem que todo crioulo já foi um pidgin, ou os que discordam diametralmente dessa proposta e dizem ser o conceito de pidgin dispensável, pois consideram o processo de formação dos crioulos um processo contínuo que só termina ou com a adoção completa da língua dominante - visão do superstratista Chaudeson ${ }^{8}$ - ou com a perda completa da língua africana de origem - visão do substratista Alleyne ${ }^{9}$-, não havendo necessidade de se denominar um estágio intermediário de pidgin e outro de crioulo, pois o estágio final é o que se chama de descrioulização, a aproximação extrema da língua europeia.

Nos dois casos, por esses dizeres, a língua resultante nessa disputa por significar-se e significar seu espaço e seu sujeito sai perdedora. No primeiro caso, a língua crioula perde para a língua europeia, porque, ao ser significada como tendo essa origem pidginizada, já está chancelada pelo discurso científico da sociolinguística que "pidgin não é língua materna de ninguém" - nos dizeres de Hall, Bickerton, Mota, por exemplo:

Pidgins e crioulos constituem dois aspectos de um mesmo processo linguístico, distinguindo-se, em termos muito gerais, pelo facto de um pidgin ser uma língua segunda enquanto um crioulo é língua primeira, ou seja, tem falantes nativos, é a língua que estes falantes melhor dominam; por outro lado, um Crioulo é geneticamente um descendente de um pidgin (MOTA, 1996, p. 505)

É importante apontar aqui o que é significado como herança dessa língua "nova" que se torna língua materna de uma comunidade de falantes. $\mathrm{O}$ crioulo, ao assim ser classificado, herda as características do pidgin que lhe originou. E, como os pidgins são caracterizados pela sociolinguística? As línguas pidgins são ditas "preencher funçôes sociais limitadas, sobretudo aquelas vinculadas a atividades comerciais mercantilistas"; são "falares de

${ }^{8}$ CHAUDESON, Robert. Dês îles, dês hommes, dês langues. Paris: L'Harmattan, 1992.

${ }^{9}$ ALLEYNE, Mervyn. Studies in Saramacan Language structure. ATW/FSP: Caribbean Culture Studies 2, 1987. 
emergência que podem se diluir e desaparecer"; são línguas que "sofrem uma simplificação e uma redução nos níveis fonológico, morfológico, sintático e lexical".

Os primeiros observadores - viajantes, comerciantes, e outros - referiam-se aos pidgins como versōes "corruptas", "bastardas" e "erradas" das línguas europeias (TARALLO, 1987, p. 88).

Alan Baxter (1996, p. 535) diz,

A pidginizaçao, a criação de uma língua pidgin, geralmente reduz ao mínimo as complicaçóes gramaticais, tais como a flexáo e as regras de concordância. $\mathrm{O}$ resultado é uma estrutura maximamente analítica desprovida de redundâncias e de ambiguidades. O léxico também é reduzido de forma drástica, mas as suas possibilidades expressivas são aumentadas pela homonímia e por meio de circunlocuçóes.

Tarallo (1987, p. 86) aduz que os pidgins são "um meio de contato que, conforme caracterizado, sofre de sérias restriçóes funcionais e discursivas".

Pereira (1996, p. 554), ao falar dos crioulos como provenientes dos pidgins comenta-os como "uma forma de linguagem deficiente, como é um pidgin".

Veiga (1995, p. 23) também dissertando sobre a origem do crioulo cabo-verdiano observa,

o primeiro estatuto desse instrumento seria o de pidgin, por ser um meio de comunicação instável que não obedece a uma estrutura definida, com parcos recursos lexicais e gramaticais, funcionando mais na base de parataxe (ausência de hierarquização e de relação sintácticas) do que de sintaxe.

Assim, voltando ao primeiro caso, as línguas outras, as línguas em espaço cabo-verdiano, por exemplo, as línguas dos povos dominados num processo colonizador, as línguas classificadas e definidas como línguas crioulas pelo discurso científico linguístico, saem perdedoras em efeitos de sentidos porque são significadas como as línguas que herdam as designaçôes e denominaçôes como "língua de ninguém", "com sérias restriçôes funcionais e discursivas", "com parcos recursos lexicais e gramaticais”. É lendo a historicidade desse arquivo discursivo da ciência linguística sobre 
as línguas crioulas que se compreende o funcionamento de uma memória discursiva que faz esquecer, mas não desaparecer, os efeitos de sentidos produzidos pela ideologia colonialista, que tentava explicar o surgimento dos crioulos como "língua dos povos colonizados", "inferiores ao europeu cultural e socioeconomicamente", "falantes de línguas com papel marginal na formação dos crioulos".

Voltando ao segundo caso, em que as línguas africanas estão completamente excluídas do processo de formação dos crioulos, também aqui, a língua "nova" sai perdedora. Segundo J. G. Herculano de Carvalho ${ }^{10}$ (1969, p. 50-51), linguista português adepto da hipótese superstratista, "os idiomas crioulos representam formas alteradas (mais ou menos profundamente, conforme os casos) de idiomas europeus". A crioulista alemã Annegret Bollée (1977) afirma de forma explícita ser partidária do que chama Evolutionstheorie, ou seja, de que os crioulos são continuadores diretos das línguas dominantes europeias.

Nesse discurso os efeitos de sentido produzem sua filiaçáo à ideologia da pureza das línguas, que levava a crer que toda língua deve provir de outra que é sua "mãe", que não havia língua mista (Max Muller). Aqui, é pertinente retomar a ideia de Renée Balibar ${ }^{11}$ (1985) de colinguismo. Nesse conceito a autora designa a necessidade de certas línguas de Estado se associarem a um aparelho de línguas em que encontrem legitimidade, estando oficialmente e gramaticalmente vinculadas à sua língua-máe (como o latim, o grego) e também às suas parceiras. Mesmo o conhecimento das línguas pidgins e crioulas vindo subverter a ideologia da pureza das línguas subjacente à teoria da árvore genealógica, tornando clara a questão da mescla linguística, ainda assim, hoje, linguistas se preocupam em buscar derivar essas línguas de uma árvore que as "salve" de uma filiação comprometedora com a das línguas africanas, sendo por isso, filiadas às línguas europeias. Hildo Couto (1996,

\footnotetext{
${ }^{10}$ Estudos Linguísticos. Coimbra: Atlântida. Vol. 2.

${ }^{11}$ Aqui retomamos o conceito de Renée Balibar (1985, p. 11-12) sobre aparelho de línguas, já mencionado, formulação produzida a partir do conceito althusseriano de aparelhos ideológicos de Estado para afirmar que a língua francesa está "além do próprio aparelho de Estado". Posteriormente, Mariani (2008a, p. 7) formulou sobre o conceito para falar de língua portuguesa, dizendo, "o português e a maioria das demais línguas europeias estấo em um mesmo patamar de auto- e intersustentação político-ideológica, no qual elas próprias se mantêm hierarquicamente na mesma posição em função de serem línguas nacionais". Com alcance e prestígio internacional, diríamos no caso do nosso objeto. E, a autora continua, "são línguas já instituídas e institucionalizadas porque são práticas socialmente regularizadas e repetíveis, fazendo parte desse aparelho de línguas, de um aparelho de letrados e de um sistema de ensino" (MARIANI, 2008a, p. 7).
} 
p. 223), ao comentar os motivos porque os crioulos devem ser estudados à parte das línguas não-crioulas, também se refere à ideia da pureza, dizendo "as comunidades de fala crioula são verdadeiros laboratórios linguísticos. Não porque elas sejam de natureza diferente das línguas náo crioulas, mas porque nelas tudo que ocorre com estas últimas se mostra de modo acirrado, quase em estado puro".

\section{Consideraçóes finais}

A historicidade sobre o percurso dos estudos linguísticos sobre as línguas crioulas mostra como se constituiu uma discursividade sobre as línguas em contato nos países colonizados pelos europeus.

Nomear determinadas línguas como línguas crioulas significa hierarquizar e valorar certas em detrimento de outras; significa repetir as verdades já-ditas; significa repetir o mesmo e não fazer diferente, para garantir o lugar de quem fala, e que, ao falar, produz paráfrase, reproduz sentidos hegemônicos. O verbo nomear, nesse caso, traz a escrita científica da intransitividade verbal, a que dá fôrma e forma, apaga, anula, dessubjetiva o lugar da singularidade do sujeito cabo-verdiano. O efeito desse discurso da linguística sobre as linguas crioulas "sustenta o sentido que surge e se sustenta nele. Intervém no já-dado, no já-dito” (ORLANDI, 2003, p. 13).

O aporte teórico da Análise do Discurso permitiu-nos buscar na/pela materialidade da língua a compreensão do que, no discurso, é lido como homogêneo, mas que se sabe heterogêneo em sua constituição, pois está sempre relacionado a outros discursos, num processo em que se imbricam memória e esquecimento. Assim, sob o efeito da homogeneidade que unifica em um grupo as línguas que "inexplicavelmente" precisam ser agrupadas - o grupo das línguas crioulas com os significantes crioulo e línguas crioulas -, abriga-se uma diversidade de sentidos pelos seus múltiplos modos de construção discursiva da referência que pudemos retraçar na materialidade do corpus aqui apresentado.

Apesar de o processo parafrástico do discurso científico ser dominante nos discursos sobre as línguas crioulas, negativizando-as em relação às línguas europeias, não podemos esquecer que os sentidos são múltiplos, que não há um sentido central, que há sempre outros sentidos possíveis que não perdem "a relação com os outros (implícitos)" (ORLANDI, 1988, p. 21).

Essa língua materna crioula não é igual a uma língua materna não- 
-crioula, como a língua portuguesa, que pode ocupar o lugar de língua oficial e certamente o faz.

Compreender, assim, como a língua ganhou o nome de crioula é importante para entender o menor prestígio até hoje angariado. Contudo o nome crioula, ao vestir o desejo de nomeação de uma língua nacional, significando-a, definindo-a, identificando-a e nela se reconhecendo (porque é assim que denominam sua língua, como crioula e crioulo), faz com que esse sujeito resista neste ponto mesmo de nomeá-la crioula. É o real da história acontecendo e produzindo a contradiçấo pela homonímia do nome dado pelo colonizador e certificado/legitimado pela ciência. É habitado por esse nome que o sujeito faz deslocar e abre a possiblidade mesma de que essa língua signifique outra coisa.

\section{Referências}

BAXTER, A. Línguas pidgin e crioulas. In: FARIA, Isabel Hub et al. (Org.). Introduçáo à linguística geral e portuguesa. Lisboa: Editorial Caminho, 1996. Coleção Universitária, Série Linguística. p. 535-549.

BALIBAR, R. L'institution du français. Essai sur le colinguisme des carolingiens à la République. Paris: PUF, 1985.

BRANCO, L. K. A. C. A língua em além-mar: sentidos à deriva - o discurso da CPLP sobre língua portuguesa. Tese de Doutorado, IEL, Unicamp, 2013. Disponível em: <http://repositorio.unicamp.br/handle/REPOSIP/270483>. Acesso em: dez. 2018.

Historicidade e sentidos: a palavra crioulo nos discursos sobre a língua de Cabo Verde. Dissertação de Mestrado, Instituto de Letras, UFF, 2007.

COELHO, M. T. A. D. Algumas consideraçôes sobre Hamlet. Revista Berggasse 19, Escola Lacaniana de Psicanálise, Rio de Janeiro, ELP, v. 1, p. 87-96, 2007. 
COELHO, A. Os dialectos romanicos ou neo-latinos na Africa, Asia e America. Lisboa: Casa da Sociedade de Geographia, 1881.

COUTO, H. H. Introduçáo ao estudo das línguas crioulas e pídgins. Brasília: Editora da Universidade de Brasília, 1996.

CUNHA, C. Língua, naçáo, alienaçáo. Rio de Janeiro: Nova Fronteira, 1981.

DeCAMP, D. Introduction: the study of pidgin and creole languages. In: HYMES, D. (Org.). Pidginization and creolization of languages. Cambridge: Cambridge University Press, 1971. p. 13-39.

FOUCAULT, M. O Poder psiquiátrico. São Paulo: Martins Fontes, 2006.

FREUD, S. Moisés e o Monoteísmo, Esboço de Psicanálise e outros trabalhos (1937-1939). Trad. Jayme Salomão. Rio de Janeiro: Imago, 2006.

Parte I - Parapraxias. In: Conferências introdutórias sobre psicanálise (Partes I e II). Rio de Janeiro: Imago Editora, 1996. v. XV. p. $08-35$.

GINZBURG, C. Mitos, emblemas, sinais: morfologia e história. 2. ed. São Paulo: Companhia das Letras, 2003.

GUIMARÁES, E. Semântica do Acontecimento: um estudo enunciativo da designação. Campinas: Pontes, 2005 [2002].

TAYLOR, D.; HALL, R. Pidgin and Creole Languages. Language, v. 43, n. 3, p. 817-824, 1967.

HENRY, P. A ferramenta imperfeita. Campinas: Unicamp, 1992 [1977]. 
. Os fundamentos da "Análise Automática do Discurso" de Michel Pêcheux (1969). In: HAK, T.; GADET, F. (Orgs.). Por uma análise automática do discurso: uma introdução à obra de Michel Pêcheux. Campinas: Unicamp, 1997 [1983]. p. 13-38.

HYMES, D. (Org.). Pidginization and creolization of languages. Cambridge: Cambridge University Press, 1971.

MARIANI, B. Da colonização linguística portuguesa à economia neoliberal: nações plurilíngues. Gragoatá, Niterói, n. 24, p. 71-88, jan./jul. 2008.

. Quanto vale uma língua? O apagamento do político nas relaçóes econômicas e lingüisticas. Encontro de Vista, v. 02, jun-dez. 2008a. p. $1-12$.

O PCB e a imprensa: os comunistas no imaginário dos jornais 1922-1989. Rio de Janeiro: Revan; Campinas: Unicamp, 1998.

MOTA, M. A. C. da. Línguas em contato. In: FARIA, Isabel Hub et al. (Orgs.). Introduçáo à linguística geral e portuguesa. Lisboa: Editorial Caminho, 1996. p. 505- 533.

ORLANDI, E. Língua brasileira e outras histórias: discurso sobre a língua e ensino no Brasil. Campinas: RG, 2009.

Interpretaçáo: autoria, leitura e efeitos do trabalho simbólico. Campinas: Pontes, 2004.

Análise de Discurso: princípios e procedimentos. Campinas: Pontes, 2003.

(Org.). História das ideias linguísticas: a construção do saber metalinguístico e constituição da língua nacional. Campinas: Pontes; Cárceres, MT: Unemat, 2001. 
. Discurso e texto: formulação e circulação dos sentidos. Campinas: Pontes, 2001a.

. Discurso e leitura. São Paulo: Cortez, 1988.

A sociolinguística, a teoria da enunciação e a análise do discurso (convençấo e linguagem). In: . A linguagem e seu funcionamento: as formas do discurso. São Paulo: Brasiliense, 1983b. p. 88-104.

PÊCHEUX, M. Abertura do colóquio. In: CONAIN, B. et al. (Orgs.). Materialidades discursivas. Campinas: Unicamp, 2016. p. 23-29.

Ler o Arquivo Hoje. Traduzido por M.G.L.M. do Amaral. In: ORLANDI, E. (Org.). Gestos de leitura: da história no discurso. 2. ed. Campinas: Unicamp, 2010 [1994]. p. 49-59.

Semântica e discurso: uma crítica à afirmação do óbvio. Campinas: Editora da Unicamp, 1997 [1975].

Análise automática do discurso (AAD-69). Trad. E. Orlandi. In: GADET, F.; HAK, T. (Orgs.). Por uma análise automática do discurso: uma introdução à obra de Michel Pêcheux. Campinas: Unicamp, 1997 [1969]. p. 61-161.

PORGE, E. A ronda dos semi-ditos claros. Trad. Paulo Sérgio de Souza Jr. (mimeo), 2010.

RANCIÈRE, J. A partilha do sensível. São Paulo: Editora 34, 2004.

SILVA NETO, S. da. História da língua portuguesa. 1. ed. Rio de Janeiro: Presença, 1957.

TARALLO, F.; ALKMIN, T. Falares crioulos: Línguas em contato. São Paulo: Ática, 1987. 
VEIGA, M. A sementeira. Portugal: ALAC, 1994.

O crioulo de Cabo Verde: Introdução à gramática. Mindelo: Instituto Cabo-verdiano do Livro e do Disco; Instituto Nacional da Cultura, 1995.

Recebido: 16/07/2018

Aceito: 09/12/2018

DOI: $10.5902 / 2179219433708$ 